\title{
TU ÉS NOSSO PAI, NOSSO RESGATADOR (Is 63,15-64,11)
}

You are our Father, our Redeemer (Isa 63:15-64:11)

Zuleica Aparecida Silvano *

RESUMO: A raiz hebraica גאל (G'L) é típica do Dêutero-Isaías, mas também ocorre no Trito-Isaías, sendo o fato dificilmente aprofundado pelos comentadores. Desse modo, nossa intenção é analisar, por meio do método histórico-crítico-literário, a lamentação descrita em Is 63,15-64,11. Além de ser um dos raros textos do AT a designar YHWH com o título de Pai, por conter a última ocorrência do radical $\left(G^{\prime} L\right)$ no Trito-Isaías; expressa a necessidade da ação resgatadora de Deus. Ao unir o goelato e a paternidade divina acentua a responsabilidade de Deus de resgatar o seu povo desta realidade desoladora e desempenhar sua função de proteger a família (Ex 6,2-6) e de ser solidário com seu sofrimento. É um texto que está em sintonia com a lamentação de nosso povo latino-americano, diante do sofrimento e do aparente silêncio de Deus.

PALAVRAS-CHAVE: Goelato. Trito-Isaías. Deus-Pai. Is 63,15-64,11. Lamentação.

\begin{abstract}
The Hebrew root $\left(G^{\prime} L\right)$ is typical of Deutero-Isaiah, but also occurs in Trito-Isaías, and commentators find it hard to deepen. In this way, our intention is to analyze the lamentation described in Isa 63:15-64:11, using the historical-critical-literary method. In addition to being one of the rare OT texts to designate YHWH as Father, it contains the last occurrence of the radical $\left(G^{\prime} L\right)$ in Trito-Isaiah, and expresses the need for God's redemptive action. By uniting the $g \hat{o}^{\prime} \bar{e} l$ institution and paternity, it stresses God's responsibility to rescue his people from this desolate reality, to fulfill his function of protecting the family (Ex 6:2-6), and to be in solidarity with his people's suffering. It is a text that is in alignment with the lamentation of our Latin American people, in the face of suffering and the apparent silence of God.
\end{abstract}

KEYWORDS: Gô'êl Institution. Trito-Isaiah. God Father. Isa 63:15-64:11. Lamentation.

* Faculdade Jesuíta de Filosofia e Teologia, Belo Horizonte, Minas Gerais, Brasil. 


\section{Introdução}

$\mathrm{O}_{\mathrm{D}}^{\mathrm{ratat}}$ גאל ג' ג' Dêutero-Isaías, mas também podemos verificá-lo no Trito-Isaías (Is $59,20 ; 60,16 ; 62,12 ; 63.4 .9 .16)$, sendo, no entanto, pouco aprofundado pelos comentadores. Uma característica peculiar do Terceiro Isaías é a ocorrência de גאל quatro ocorrências de גאל (G'L), sendo três com o significado de "resgatar" (vv. 4.9.16) e uma, de sua homógrafa, com o sentido de "contaminar", "profanar", "manchar" (v. 3).

Nossa intenção é analisar exegeticamente Is 63,15-64,11, por meio do método histórico-crítico-literário e apresentar o clamor de Israel pela ação resgatadora de Deus, num momento de grande angústia, dado que Ele é o chefe de família, o Pai de Israel. Essa perícope foi selecionada por conter a última ocorrência da raiz hebraica em questão no Trito-Isaías $(63,16)$ e por designar Deus com o título de Pai, sendo uma raridade no AT. Outra motivação para escolhê-la é por expressar o aparente silêncio de Deus diante do sofrimento do povo, aspecto também presente em nossas inquietações ao contemplarmos a angústia de nosso povo latino-americano.

\section{Organização do texto}

Percebe-se uma unidade entre Is 63,7-64,11, tendo como moldura Is 63,7 (introdução) e 64,9-11 (conclusão) e duas partes centrais: Is 63,8-14 e 63,15-64,8.

Entre a introdução e o final há um contraste, pois se inicia apresentando a grandeza das manifestações e os prodígios realizados por YHWH no passado (Is 63,7) e se termina com a súplica a Deus diante da destruição e da desolação no presente. Esse contraste é mantido nas duas partes da perícope. Na primeira, o orante recorda os prodígios feitos por Deus, sua presença constante e a relação pessoal com Ele. Esses dados são alternados com a rebeldia do povo, mas, mesmo infiel, ele continua sendo escolhido, salvo e perdoado por YHWH. Deste modo, o orante sintetiza a trajetória da história de Israel.

Nos vv. 15-19a, há a súplica e uma acusação devido à indiferença divina e à falta de solidariedade para com seu povo. Nos versículos centrais $(63,19 b-$ $-64,4 a)$, o autor mantém a recriminação, mas, também, expressa sua confiança em YHWH. Conclui-se com a confissão dos pecados, a consciência do afastamento do povo e da ruptura da Aliança com Deus $(64,4 b-8)$. O tema da paternidade divina está presente na primeira parte como forma de motivar a acusação contra Deus e, na segunda, fundamenta a fé da comunidade. 
Não há grandes problemas quanto à delimitação do texto em questão, pela unidade literária na seção de Is 63,15-64,11. Individualizam-se vários recursos estilísticos como a inclusão entre Is 63,15 e 64,11 com a raiz verbal ('PQ) e as perguntas retóricas; o uso do Tetragrama (63,16.17; 64,7-8.11), a repetição dos substantivos שִ (šem) em 63,16.19; 64,1.6; צִּ (șar)

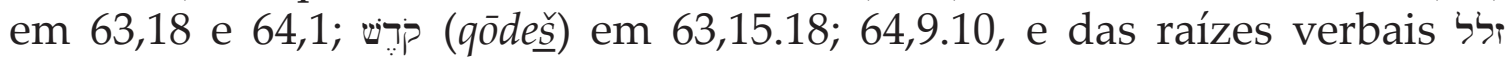
(ZLL) em 63,19 e 64,1, e ידע (YD') em 63,16 e 64,1. Outros recursos literários e teológicos são a referência à destruição do templo $(63,18$ e 64,10), o uso da locução "és nosso pai", dirigida a YHWH (Is 63,16; 64,7), além dos ligames lexicais no interior de Is $63,15-19^{1}$ e Is $64,1-11^{2}$.

Is $63,15-64,11$ intensifica a lamentação presente na perícope precedente (vv. 7-14), sublinhando o reconhecimento e a confissão dos pecados cometidos por Israel (Is 64,4-6.8).

\section{Is 63,15-64,11: tradução}

${ }^{63,15}$ Olha desde o céu e vê de tua santa e gloriosa morada. Onde estão teu zelo e tuas potestades ${ }^{3}$ ? A comoção de tuas entranhas e de tua compaixão para comigo foram contidas?

${ }^{16}$ Mas tu és nosso Pai, ainda que Abraão não nos conheça e Israel não nos reconheça; tu, ó YHWH, és nosso Pai; nosso resgatador desde a antiguidade é o teu nome.

${ }^{17} \mathrm{YHWH}$, por que nos fazes extraviar de teus caminhos? Por que endureces nosso coração, para que não te temamos? Volta, por amor de teus servos e das tribos de tua herança.

${ }^{18}$ Só por breve tempo assenhorearam-se ${ }^{4}$ de teu santo povo; nossos adversários pisotearam teu santuário.

${ }^{19} \mathrm{Há}$ muito tempo estamos como aqueles que não governaste, como aqueles sobre os quais não foi invocado o teu nome. Oxalá, tivesses rasgado os céus, tivesses descido! Diante de ti as montanhas teriam tremido, ${ }^{64,1}$ como o fogo que inflama os gravetos, como o fogo que faz ferver as águas, para fazer conhecer o teu nome aos teus adversários e as nações tremessem à tua presença!

\footnotetext{
${ }^{1}$ Isso é observado na inclusão do termo "céu" (vv. 15 e 19); nas duas repetições do termo "pai" (63,16 e 64,7); na referência à santidade da morada divina e do povo (vv. 15.18) e na repetição do termo "nome" (vv. 16.19).

2 Constata-se na repetição dos termos "nome" (vv. 1.6), "iniquidade" (vv. 6.8), YHWH (vv. 8.11), "fogo" (vv. 1.10), "justiça" (vv. 4.5); na referência à santidade das cidades e do templo (vv. 9.10).

${ }^{3}$ No TM, está no plural. Por ser um termo "abstrato", algumas versões antigas traduzem-no com um substantivo no singular.

${ }^{4} \mathrm{O}$ radical $Y R \zeta$, na forma qal, pode ser traduzido por "expulsar o proprietário", "expropriar", "apropriar-se", "apoderar-se", "conquistar", "possuir".
} 
${ }^{2}$ Quando fizeste coisas terríveis, que não esperávamos, desceste, e os montes tremeram à tua presença.

${ }^{3}$ Porque desde a antiguidade não se escutou nem se ouviu, nem os olhos viram Deus, além de ti, que age assim para com aquele que nele espera.

${ }^{4}$ Oxalá, tivesses saído ao encontro daquele que se alegra e pratica justiça, daqueles que se recordam de ti em teus caminhos ${ }^{5}$; eis que te iraste ${ }^{6}$, nós pecamos por muito tempo ${ }^{7}$ : havemos de ser salvos?

${ }^{5}$ Mas somos como o impuro, todos nós; e como pano de menstruação todas as nossas obras justas ; murchamos como a folha, todos nós, e nossas iniquidades, como o vento, nos arrebatam.

${ }^{6}$ Ninguém invoca o teu nome, nem quem se desperte para aderir a ti; porque escondes de nós o rosto e nos abandonas nas mãos de nossas iniquidades.

${ }^{7}$ Mas agora, ó YHWH, tu és nosso Pai, nós somos o barro, e tu, aquele que nos formaste; e todos nós, obra de tuas mãos.

${ }^{8} \mathrm{Não}$ te enfureças excessivamente, ó $\mathrm{YHWH}$, nem perpetuamente te lembres (recordes) de nossa iniquidade; eis, pois, nós te pedimos: todos nós somos teu povo.

${ }^{9}$ As tuas santas cidades são um deserto, Sião é um deserto; Jerusalém está desolada.

${ }^{10} \mathrm{O}$ nosso templo santo, nosso esplendor, em que nossos pais te louvavam, tornou-se pasto de fogo, todas as nossas coisas preciosas se tornaram em ruínas.

${ }^{11}$ Por acaso, diante disso podes te manter contido ${ }^{9}, \mathrm{YHWH}$ ? Permanecerás calado e nos humilharás muito mais?

\section{Análise literária e teológica}

Em Is 63,15-64,11, entrecruzam-se perguntas retóricas, confissão de confiança na paternidade do Senhor, descrição da realidade de sofrimento vivido pelo povo e recordação das ações de Deus. Emprega-se um grande

\footnotetext{
${ }^{5}$ Este versículo contém inúmeros problemas textuais que serão analisados posteriormente.

${ }^{6}$ A frase não é clara e há inúmeros problemas textuais. Outra possibilidade de tradução seria "eis que te iraste e pecamos" ou ainda "eis que tu te iraste, porque pecamos" (SALVADORI, 2013, p. 154).

${ }^{7}$ Literalmente, poderia ser traduzido por: "nestes desde a antiguidade" ou "nestes para sempre". Algumas traduçoes acrescentam "caminhos", mas pode ser também "pecados" ou "iniquidades". Infelizmente não é possível definir com precisão a frase, nem recorrendo às versões antigas.

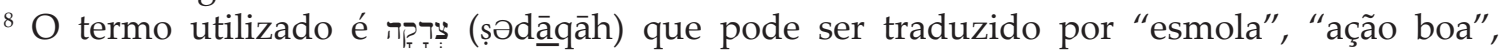
"mérito", no sentido de "fazer caridade". No judaísmo, "fazer justiça", neste caso, seria dar esmola, hospedar um peregrino, visitar os doentes, enterrar os mortos, satisfazer as necessidades de um pobre etc.

9 Pode ser entendido como manter-se "insensível", porém, continuamos com o "ser contido", pois repete o mesmo radical verbal de Is 63,15.
} 
número de imagens extraídas do âmbito familiar, penitencial e da tradição teológico-bíblica. Todos esses particulares imprimem peculiar característica ao tema do goelato. Esse conjunto estabelece, em alguns versículos, uma dramaticidade (Is 63,15.17.19; 64,5.11), transparecendo o desespero do povo diante da destruição do Templo (Is 63,18; 64,10), do pecado e da sensação de total silêncio e abandono de Deus. O "eu" do profeta ou do orante se funde com o "nós" da comunidade e o texto se configura por meio de interpelações diretas a YHWH $(\mathrm{Sl} \mathrm{80,15).}$

A perícope pode ser classificada como salmo de lamentação (Sl 25,7.11; 35,11-14; 41,5; 79,9), não obstante a constatação da confissão de culpa (Is 64,4-6), aspecto não evidente nas lamentações. Quanto aos recursos estilísticos, a sinonímia é utilizada com frequência, bem como o jogo com o significado das palavras.

As opiniões quanto à estrutura interna desse texto oscilam, devido à falta de uma nítida ligação entre as frases. A perícope é introduzida com uma oração a Deus, para que se volte para seu povo, e uma profissão de confiança, na qual são atribuídos a YHWH os títulos de Pai e Resgatador (Is 63,15-16). Segue-se uma lamentação com quatro tópicos: ter o caminho extraviado; ser dominado pelos adversários; presenciar o santuário pisoteado e ser abandonado (vv. 17-19a), que desembocam na constatação da ausência de uma intervenção divina (63,19b-64,2), em comparação com atos salvíficos de YHWH no passado (Is 64,3).

No v. 4, encontram-se vários problemas de crítica textual. Ao uni-lo aos vv. 5-7 temos como conteúdo o reconhecimento e a confissão dos pecados. Essa confissão é intercalada com outra profissão de fé em Deus como Pai e Criador (v. 7). Os vv. 8-11 retomam a lamentação presente em Is 63,15.17$19 a$, tendo como temática central a destruição de Sião e do templo. Há uma pergunta dirigida a Deus no v. 11, semelhante a Is $63,15 \mathrm{~b}$, diante de sua aparente insensibilidade.

\subsection{Lamentação do povo ao Deus resgatador: Is 63,15-64,3}

O v. 15 é semelhante ao $\mathrm{Sl} 80,15$, no qual o orante, em nome da comunidade, pede a Deus que se converta ou volte-se para o povo e que veja a situação desoladora, na qual se encontra.

O "céu" é um arquétipo para referir-se ao próprio Deus (Is 63,15) e é a expressão da transcendência divina por sua imensidão, pela distância da terra, mas, também, pelo afastamento do ser humano. O convite do orante, dirigido a Deus, para que desça de sua morada no céu, reflete a ausência de comunicação entre Deus e Israel e a concepção de um Deus completamente inatingível e tranquilo (S1 79,5; 83,2-3), distante do sofrimento da comunidade. Por outro lado, transparece a consciência da comunidade de que sua existência depende completamente d'Ele. As lamentações, 
presentes nessa seção, descrevem o desespero do povo que, ao sentir-se abandonado por Deus e longe de seu olhar salvador, é entregue nas mãos dos adversários, que pisoteiam suas cidades e o templo e os arruínam (v. 18) e, por conseguinte, destroem também o povo.

As perguntas retóricas, em Is 63,15, questionam aspectos fundamentais do relacionamento de YHWH com Israel, até então considerado povo eleito: seu zelo, sua ação redentora e potente, sua compaixão e misericórdia. Apesar do tema da paternidade ser explícito no decorrer do texto, constituindo um leitmotiv dessa lamentação, o "comover as entranhas" e o uso do termo רְחמִּים (rahămîm), traduzido por "misericórdia", são expressões próprias da maternidade. A intensidade da imagem de um Deus-Mãe, que refreia sua comoção e sua misericórdia a ponto de contê-las, ostenta uma força persuasiva, capaz de provocar no ouvinte a solidariedade com a dor que assola a comunidade, que vivencia a sensação de ser rejeitada e abandonada por Deus.

O v. 16 enfatiza a paternidade de Deus ao contrapô-la aos principais patriarcas (Abraão e Israel) e ao afirmar categoricamente que YHWH é o Pai de seu povo (duas ocorrências no v. 16 e Is 64,7).

Antes de abordar a paternidade divina, é importante compreender o não reconhecimento como filhos da parte de dois patriarcas: Abraão e Israel. Esse "não reconhecimento" pode assumir duas acepções: uma de cunho afetivo, no sentido de ser rejeitado, e a outra legal, interpretado como o não reconhecimento jurídico da filiação. Outra possibilidade, sintonizada com a segunda acepção, seria a ruptura de uma relação fundamental e as ulteriores consequências desse ato (declaração da orfandade, sem direito à filiação, à herança, cf. NISKANEN, 2006, p. 399). Essas duas compreensões são compatíveis, pois, se uma pessoa não é considerada filha, pode ser tomada por um sentimento de rejeição. Nesse contexto, a parte jurídica parece ser mais viável, pelas referências à paternidade e ao goelato.

Abraão e Israel são importantes para o período pós-exílico, por estarem nas origens do povo de Deus; por causa das promessas da terra e da descendência, e devido à Aliança (BAUTCH, 2009, p. 42-63) ${ }^{10}$. Eram considerados pais do povo (Is 51,2; 58,14; 43,27). Abraão, em Isaías, é designado o chamado $(51,2)$, o escolhido $(41,9)$, o resgatado $(29,22)$, o amigo $(41,8)$, aquele a quem Deus prometeu as bênçãos, a terra e a descendência $(51,2)$. Nos textos bíblicos, Abraão é o paradigma do fiel que observa os mandamentos de Deus, antes da Lei Mosaica (Gn 26,5). Ele garante a salvação e a bênção para seus descendentes e é o primeiro a proclamar a fé no Deus único, mesmo sendo um prosélito (SKA, 2000, p. 341-349).

${ }^{10}$ Para Bautch, alguns autores pós-exílicos ressaltam a Aliança com Abraão, enquanto outros a Aliança sinaítica. Em seu artigo, o autor sugere que o não reconhecimento dos patriarcas (Abraão e Israel) reflete a realidade polêmica entre Betel e Jerusalém (p. 52-53). 
Israel, igualmente, é o escolhido (41,8), o amado (Ml 1,2-3), aquele pelo qual Deus chama seu povo pelo nome $(45,4)$. Também, é garantia da bênção $(44,1-4)$ e do retorno à Terra Prometida.

O povo, provavelmente, não é adotado pelos Patriarcas por dois motivos: porque seu verdadeiro Pai é Deus, mas também por causa de seus pecados. Desse modo, ao não ser reconhecido pelos Patriarcas, o povo não tem mais direito às bênçãos e às promessas, e Deus não tem mais o dever de manter a Aliança feita com Abraão e com Israel, pois, apesar do caráter irrevogável e incondicional, sobretudo da Aliança com Abraão, esses aspectos não são absolutos, pois se presume que, tanto os Patriarcas como o povo, continuariam a confiar em YHWH e a trilhar seus caminhos.

Apesar de ser comum a designação de Israel como filho (Is 1,2-3; 30,9; 43,6-7; Ex 4,22-23; Jr 31,9; Os 11,1-4), as referências explícitas de Deus como "pai" são raras (Is 63,16; 64,7), não obstante as alusões às atitudes paternas e maternas atribuídas a Deus (Os 11,1-4 e SCHÜNGEL-STRAUMANN, 2003, p. 273.276-278).

No período pré-exílico, era evitado chamar Deus de Pai, para não o confundir com a visão mitológica dos deuses cananeus (CHILDS, 2005, p. 570) e a concepção mítica da paternidade física entre os deuses e seus devotos, atestada nas religiões circunvizinhas de Israel (BLENKINSOPP, 2003, p. 257 e MARCONCINI, 1999, p. 57). O uso dessa imagem é mais frequente nos textos pós-exílicos (CHILDS, 2005, p. 570), sobretudo, nos livros do período helenístico e romano ( $\mathrm{Tb} 13,4 ; \mathrm{Sb} 2,16 ; 14,3)$. Verificam-se comparações entre a relação do pai e da mãe com os filhos e as atitudes de YHWH com seu povo em Is 45,10 e S1 103,13 e, num contexto de fórmula de adoção dirigida ao rei, em $2 \mathrm{Sm} 7,14$ e no Sl 2,7. As referências explícitas da paternidade divina ocorrem em Dt 32,6; Sl 68,5; Jr 3,4.19; 31,9; Ml 1,6 e 2,10. Nesses textos, a imagem de Deus como Pai é aplicada metaforicamente e de maneira hipotética ou em forma de perguntas (Jr 3,4.19; $\mathrm{Ml} 1,6$ e 2,10). Ela é empregada, geralmente, em contextos negativos, a fim de exortar à obediência filial (Dt 32,6; Ml 2,10 e Jr 4,22) ou advertir sobre a ilusão de não ser punido ao se apelar para a paternidade divina (Ml 1,6; Jr 3,4.19 e SIMIAN, 2004, p. 100). Somente em Jr 31,9, o Senhor afirma sua paternidade como fundamento para intervir em favor de Israel, propiciando o retorno do exílio.

No Oriente Médio Antigo, a relação entre pai e filho é utilizada como metáfora para representar o vínculo entre os soberanos e seus vassalos e evocar proteção (BOVATI, 2005, p. 156). O simbolismo do "pai" também alude às origens, dado que é aquele que dá a vida e sugere a dependência dos filhos ou súditos a uma suprema autoridade. Essas características, também, estão associadas à noção de "servo", no v. 17, que aparece em Is 56,6 e retorna em $65,8.15$ e 66,14 . 
A invocação em Is 63,16 e o apelo a Deus como Pai num momento de crise objetivam a intervenção de Deus e sua ação de resgatar. Ao mesmo tempo, evidencia uma tensão entre a memória dos fatos ocorridos num passado longínquo e a ausência de uma ação salvífica em favor do povo em sua angústia presente.

As citações que expressam Deus como Pai de seu povo ou do orante e têm maior afinidade com Is 63,16 e 64,7 são Sl 68,6 e Ml 2,10. No Sl 68,6, YHWH é designado como Pai dos "órfãos e das viúvas" e aquele que defende os indefesos. Isso condiz com o conteúdo presente em Is 63,16, quando é mencionada a orfandade de Israel, dado que nem Abraão nem Israel (duas personagens centrais para o povo, cf. Gn 12,2; 13,16; 15,5; 17,56) reconhecem o povo e o acolhem como filho. Em Is 64,7, a imagem do Pai é conectada com a do oleiro, e refere-se a Deus-Pai-Criador, metáfora presente em Ml 2,10. Dessa forma, é afirmado que a filiação do povo não se reduz à sua ancestralidade humana, nem provém do vínculo de sangue, mas do pacto entre Deus e o povo no Sinai e na experiência exodal.

Tanto a paternidade como o goelato (v. 16) pertencem ao campo jurídico (S1 68,6; Jó 29,16; Is 9,5) e fazem parte do direito familiar. Possivelmente, a função de relacioná-los é a de afirmar o papel de Deus como chefe do grupo familiar e sua responsabilidade de defender, proteger e ser solidário com o povo, o qual se encontra em condição desoladora. Por isso, Deus tem o dever de exercer o goelato, resgatando o povo (v.18), a terra (Is 64,9; Ex 19,5) e o templo (Is 64,10).

O título de Pai atribuído a Deus, provavelmente, está vinculado à reconstituição da identidade da comunidade pós-exílica. Nesse sentido, é importante a relação existente entre a paternidade de Deus, o goelato, e as alusões à experiência exodal e à teofania no Sinai, em 63,19b-64,4a.

À afirmação de que o nome de YHWH é resgatador, acrescenta-se um aspecto temporal: "para sempre" (v. 16). Dizer que o ser resgatador faz parte de sua identidade (nome) significa afirmar que a promessa de libertação, de resgate, de consolação é intrínseca ao seu ser. Nesse contexto, a raiz G'L é adotada em âmbito litúrgico (lamentação) e teológico. Mantém seu sentido jurídico originário, porém, é empregado de forma metafórica.

Ao asseverar que Deus é resgatador desde a antiguidade e ao citar Moisés em Is 63,11-14, o texto refere-se à ação resgatadora de YHWH no Êxodo (Ex 6,6; 15,13; Sl 74,2 e Is 48,20). Esses aspectos elucidam a relação entre paternidade e redenção, dado que foi na promessa (Ex 6,4-6) e na libertação da escravidão do Egito que Deus tornou-se o Pai de Israel.

Deus é redentor porque resgatou seu povo do Egito e, também, resgata a terra, dando-a ao povo. Percebe-se a ênfase na necessidade da intervenção salvífica, no apelo às duas instituições jurídicas (Pai e Resgatador) e 
a urgência do resgate do que pertence a Deus desde sempre. Contudo, cria-se uma tensão no uso dos termos "Pai" e "Resgatador", dado que o vocábulo "pai" traz em seu bojo a responsabilidade de defender seus filhos, sem a necessidade de apelar para a instituição do goelato. Mas, como foi visto anteriormente, essas duas instituições aludem à experiência exodal e têm a intenção de intensificar o lamento. $\mathrm{O}$ apelo ao pai também expressa a certeza do amor gratuito, capaz de perdoar, de acolher e de dar outra chance. Nesse sentido, é significativo o uso de נִ נְלְלָה (nahălāh - v. 17), dado que a herança e o goelato pertencem ao mesmo campo semântico (S1 74,2; Rt 4,6).

O termo נַחלָלה (nahălāh) pode estar coligado com a tradição cultual, para expressar o senhorio de Deus, mas também para designar o povo ${ }^{11}$. Israel é herança de Deus a partir da libertação do Egito, e este aspecto o diferencia das outras nações. O povo tornou-se também a herança de Deus por ter sido criado e escolhido por Ele, e por ter estabelecido uma Aliança com YHWH (Dt 4,20; 1Rs 8,53; Sl 33,12). A designação "tribos de sua herança" comprova a natureza estável e duradoura da posse (Jr 10,16; 51,19; Sl 74,2; Ex 15,17). No entanto, havia a possibilidade de Deus abandonar a terra e sua herança (o povo) quando se tornavam impuras (cf. Jr 12,7-8; Ez 9,3; 11,22-23; Zc 2,16). Por conseguinte, o povo, o templo e a terra sem a presença divina ficaram privados de uma divindade protetora. Declarar que um povo era desprovido de sua divindade, significava anunciar sua total destruição, a ruína, como presa fácil dos adversários. Esses aspectos transparecem na súplica do orante, no v. 17, que clama o retorno de Deus para as tribos de sua herança e expressa a dor por sofrer a dominação dos inimigos e a profanação do templo (v. 18). Essa realidade gera a ruptura do relacionamento e do pacto entre Deus e o povo (vv. 15.17.19).

Diante desse quadro lastimável, o povo clama a Deus como Pai e Redentor e recorda os aspectos fundamentais de sua fé que o fortaleceram no decorrer da história, a saber, a confiança na presença salvífica de Deus (Is $63,9)$ e a certeza de que não foi Moisés quem conduziu o povo no deserto, mas o Espírito de YHWH (63,11-14). Isso leva a entender que os Patriarcas não são os pais de Israel, e sim, o próprio Deus (Is 64,7).

A súplica a Deus e sua possível ação salvífica não se baseiam nos méritos do povo, por ser um povo infiel, mas na relação e na responsabilidade que YHWH tem com a comunidade pós-exílica. Deus age gratuitamente por fidelidade às Alianças realizadas com o povo de Israel, independente da rebeldia do povo.

${ }^{11}$ Dt 4,20; 9,26.29; 32,9; 1 Sm 10,1; 2Sm 14,16; 20,19; 21,3; 1Rs 8,51.53; 2Rs 21,14; Is 19,$25 ; 47,6$; Jr 10,16 = 51,19; Mq 7,14.18; Jl 2,17; 4,2; Sl 28,9; 33,12; 74,2; 78,62.71; 94,5.14; 106,5.40. Em todos esses casos o termo se refere ao povo de Deus, exceto $2 \mathrm{Sm} 20,19$, no qual há uma referência à entidade política ou, segundo alguns autores, à terra. 
As perguntas, no v. 17, dirigidas a Deus, podem ser interpretadas tanto por acusação quanto por repreensão. As duas primeiras conectam a concepção da unicidade de YHWH e a questão do mal. Isso implica que Ele pode desviar o caminho de Israel e endurecer o coração de seu povo (Is 45,6-7), duas atitudes atribuídas ao faraó do Egito, figura simbólica do mistério do pecado (PRIOTTO, 2014, p. 161-163).

O "desviar o povo do caminho" evoca a dimensão ética, ou seja, o não agir conforme o direito e a justiça, exprimindo a ideia de pecado e suas consequências. Quando o sujeito do verbo תעה (T'H), em seu uso metafórico-causativo, é Deus, normalmente, indica o poder divino e sua ação punitiva (S1 107,40; Jó 12, 24-25; Is 30,18). Assim, Is 63,17 pode assumir dupla acepção. A primeira responsabiliza Deus por ser uma ação provocada por Ele, ao "desviar o caminho de seu povo", enfatizando sua soberania. A segunda é expressa como um ato punitivo de Deus em face da transgressão de seu povo. Portanto, a ação humana está em sua origem.

Apesar da expressão "endurecer o coração" ser usual nos textos bíblicos, a raiz קש $(Q S \zeta H)$, traduzida com o verbo "endurecer", ocorre neste texto e em Jó 39,16. A locução supramencionada pode ser entendida como o não cumprir a vontade de Deus; o afastar-se de sua mensagem (Ex 8,11.28 e Am 4,6-12), e ser uma consequência da ruptura da Aliança entre Deus e o povo (v. 19; Is 6,9-10 e 64,4-6).

O "endurecer o coração" representa uma opção consciente de opor-se a Deus. Desse modo, a realidade sofrida em que o povo se encontra é interpretada como castigo de Deus, pela ação do povo contra Ele, semelhante aos prodígios realizados contra o faraó e o Egito. Esse aparente castigo, tanto em Êxodo como neste contexto, é um sinal enviado, visando à conversão e à salvação do povo. Deus é amor, mas não pode manter-se indiferente à obstinação do povo ao pecado. Pode livremente elegê-lo, manifestar gratuitamente sua glória, mas também rejeitá-lo. Essa consciência muda a concepção de Israel como povo eleito, pois apesar de ser consagrado, o povo não pode agir sem ter presente a responsabilidade de testemunhar e sua missão de ser luz para as outras nações. Desse modo, sua atitude pecadora pode levá-lo à total destruição. Surge, ainda, a consciência da misericórdia de Deus, que pode dar mais uma chance e intervir sem contar com a fidelidade do povo, se esse reconhecer seu pecado.

Observa-se que, em Is 63,19b-64,2, há um conflito de concepções: pois, se de um lado, o povo se considera eleito e, por conseguinte, isento da rejeição de Deus; por outro, transparece a constatação de que Deus não se revela com potência e majestade para socorrer Israel, conforme o desejo do povo (Is 48,18). Isso é explícito na relação entre Is 63,19 e 64,1, dado que há uma reivindicação da parte do povo, ao acusar Deus por sua ausência, e uma súplica pela intervenção direta. A intervenção é delineada por meio 
de imagens teofânicas, como: "rasgar o céu", "tremer os montes" e "fogo". Esses aspectos estão presentes na manifestação no Sinai (Ex 19,16-20,3) e são característicos do chamado "Dia do Senhor" e da tradição apocalíptica (COLLINS, 2010, p. 48-52).

\section{2 "Confissão" dos pecados: Is 64,4-6}

A tensão referida anteriormente também é retratada no v. 4, que, apesar dos vários problemas textuais e da possibilidade de interpretar a primeira frase de forma tanto negativa como positiva, provavelmente, indica a desilusão de um desejo que parecia ser possível e viável, mas não foi realizado (Is 48,18). O lamento do povo assemelha-se à intercessão de Abraão em favor de Sodoma e Gomorra (Gn 18,17-33), apelando para a absolvição dos pecados e a obtenção dos benefícios de Deus, mesmo que fosse por meio de alguns justos presentes no meio deles. Mas, semelhante àquelas duas cidades, não foi encontrado justo algum que legitimasse a ação benevolente de Deus (Is 59,1-15).

O v. 4 pode ser lido da seguinte forma: "porque te iraste, nós pecamos". Desse modo, responsabiliza a ira de Deus pelo pecado do povo. Infelizmente, não se encontra uma tradução viável para este versículo, nem recorrendo às versões antigas por constatar que nessas versões a frase é modificada, harmonizando-a com o contexto ou simplificando-a. Não obstante essa dificuldade, ao considerar os vv. 5-6, podemos afirmar que há uma confissão explícita das iniquidades e da realidade de impureza da comunidade. Mas o orante não deseja assumir toda a responsabilidade, pois Deus poderia ter ajudado o povo eleito (v. 4), por ser o único criador e Senhor da história.

O sofrimento do povo, que perpassa a perícope em questão, não é apenas a experiência do exílio, de ser pisoteado ou de presenciar sua cidade e o templo destruídos, mas é o afastamento de Deus e o não reconhecimento como filho, por causa do pecado (Is 63,10; 64,5). Entretanto, Israel mantém a certeza da misericórdia de Deus e de que um pai sempre permanece pai, mesmo que se irrite e castigue seus filhos. Por isso, Israel apela desesperadamente para a paternidade divina. Isso também acentua o caráter unilateral da Aliança.

As imagens do v. 5 para retratar a consequência da iniquidade e da impureza do povo são eloquentes e, de certa forma, contribuem para a compreensão dos problemas textuais presentes no texto.

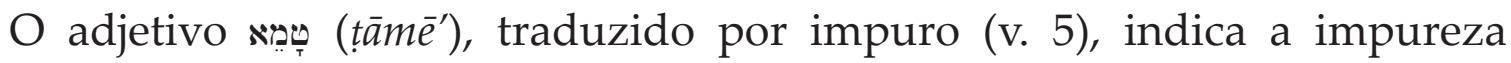
ritual, aquela contraída pela não observância das prescrições ligadas ao culto. Nesse tipo de impureza, a comunidade ou a pessoa não podia se aproximar de Deus e necessitava de uma purificação proveniente d'Ele. 
A referência à impureza está em oposição à santidade divina, retratada na alusão à santa morada de Deus (Is 63,15) e nas imagens teofânicas (Is 63,19-64,2), e visa a justificar a não manifestação de Deus.

A primeira imagem é a do pano de menstruação que é empregado para sublinhar a impureza (Lv 15,19-24). Ela é utilizada para referir-se às obras justas, o que superficialmente poderia parecer paradoxal, por transformar algo positivo em impuro. Ao relacionar a impureza proveniente do contato com o pano de menstruação com as "obras justas" da comunidade, o orante radicaliza o sentimento de rejeição, pois da mesma forma que a mulher menstruada é proibida de relacionar-se com seu marido e com as pessoas, de participar do culto e de ter contato com o sagrado, também para a comunidade é vetado o contato harmonioso com Deus e com as pessoas, por ser ela impura. Assim, suas obras justas tornam-se uma força hostil, transformando-se em infecunda, sem vida e ameaçadora.

A dimensão ética está presente na segunda imagem que é aplicada à iniquidade. A "folha murcha" é adotada nos oráculos de acusação (Is 1,30 e 34,4), como símbolo da punição, do juízo divino (Is 28,1-5; 37,27 e S1 37,2) e da fragilidade (Jó 13,25). No Sl 1, a "palha" levada pelo vento representa a ação dos ímpios, em contraposição à consistência da árvore junto aos riachos, pois suas folhas nunca murcham. Essa última imagem representa o justo, que age conforme a Lei do Senhor e, por isso, tudo o que faz é bem-sucedido, enquanto a palha é o símbolo da morte e da inconsistência, que tende a desaparecer completamente, semelhante à "folha seca". Isso é corroborado pelo uso da raiz נשא (NŚ), que também tem o sentido de "fazer desaparecer" (Is 40,24b; 41,16a; 57,13a). Neste contexto, a "folha seca" representa a iniquidade, e a palha no $S 1$ 1,4, o ímpio.

Percebe-se que pecado, iniquidade e impureza são conceitos que se interligam, mas não são idênticos. São utilizados como forma de enfatizar a realidade de pecado do povo.

O esquecimento de YHWH é total, pela constatação de que ninguém suplica o dom da salvação, nem cultiva uma relação de amor e dependência com Deus (v. 6).

Há uma particular fineza e um trato de grande profundidade teológica (vv. 7-8), ao referir-se a Deus-Pai como "aquele que modela" (Gn 2,7-8; Is 29,16 e 45,9-11). A expressão "nós somos o barro" (v. 7) pode ser interpretada como reconhecimento do ser criatura, mas, também, da própria condição de transitoriedade, de fragilidade e de limitação. Ao mesmo tempo, exprime o desejo de ser salvo, de obter a misericórdia e o perdão divinos.

Ao relacionar essa questão com a criação, alguns comentadores discordam de que haja uma visão universalista quando YHWH é chamado de Pai e 
Criador, mas sublinham que esses títulos visam a reafirmar a relação paternal entre Deus e Israel (cf. Jr 31,9; Ex 4,22-23; 15,16; Dt 32,5-9 e NISKANEN, 2006, p. 406). Além disso, esses epítetos estabelecem uma afinidade entre a criação e a constituição como povo, na experiência exodal. Dessa forma, mantém-se a tensão entre o universal e o particular, entre Israel e as outras nações.

Os vv. 8-11 podem ser interpretados à luz dos $\mathrm{Sl}$ 77,6-10 e 106. A lamentação pela profanação e devastação do santuário (vv. 9-10) está em estreita relação com o Livro da Lamentação (BLENKINSOPP, 2003, p. 265-266). Entre os pontos de contato, destacam-se: a) o reconhecimento de que o causador da catástrofe tenha sido o próprio Deus, como iniciativa de sua ira diante da rebeldia de Israel; os inimigos são instrumentos utilizados por Ele; b) Jerusalém e o povo tornam-se impuros (Lm 1,8a; 3,42; 4,6.13 e Is 64,4-6); c) existe uma tensão entre a confissão de fé em YHWH e o desespero; o reconhecimento da culpa coletiva e a acusação pelo abandono de Deus; a lamentação e a acusação, a crise diante da destruição e a fé, e d) a sensação de ser repudiado e abandonado por YHWH (MORLA ASENSIO, 2004, p. 19-57).

O profeta-orante também tem consciência de que o pecado de Jerusalém/ Israel ultrapassou os limites de uma promessa incondicional com relação à inviolabilidade de Sião. Isso é retratado nos acontecimentos históricos citados no texto, provavelmente, referindo-se à tomada de Jerusalém e à experiência do exílio babilônico (Lm 1,7-10).

Na lamentação de Is 63,7-64,11, o resgate também pode ser visto como o perdão dos pecados (Is 63,17; 64,4-8). Percebe-se novamente que esse texto mantém a relação entre a $\left(G^{\prime} L\right)$, o tema da criação e da santidade (também Is 43,6-7.15.22; 44,2.21.24 e 45,10-11) e estreita o vínculo entre paternidade, adoção e redenção.

\section{Conclusão}

Predomina em Is 63,7-64,11 o uso da raiz גאל (G'L) num contexto de ruptura da Aliança e da necessidade do povo ser resgatado do pecado, da injustiça, das transgressões, da aflição (Is 64,9) e de estabelecer o direito e a justiça. Assim, é importante uma Nova Aliança entre Deus e o povo. Percebe-se nessa perícope a influência da tradição exodal e o vínculo entre ser resgatado (Is 63,10) e ser santificado (Ex 6,2-6).

O goelato é utilizado de forma metafórica, predominando as imagens vinculadas ao contexto familiar. Designar Deus como $(g \hat{a}$ ' Ele tivesse uma obrigação jurídica de interferir em favor de seu povo, de 
ser solidário com ele, e, dessa forma, reafirmar seu vínculo de parentesco com Israel.

A perícope termina com a súplica dilaceradora do povo diante do sofrimento e a espera da manifestação de Deus, que é o resgatador, mas acima de tudo é Pai.

Diante do clamor do povo de Israel descrito em Is 63,15-64,11, fazemos memória dos inúmeros clamores do povo diante da realidade de violência, do massacre dos indígenas, dos pobres definhando em nossas cidades, das crianças sem esperança, jovens sem perspectivas, dos anciãos rejeitados, das pessoas injustiçadas, ou seja, de tantos corpos pisoteados, templos de Deus.

Ao ver essa situação nasce em nosso coração a mesma lamentação do orante-profeta contra Deus: "A comoção de tuas entranhas e de tua compaixão para conosco foram contidas?" Como o povo de ontem, também hoje somos surpreendidos pelo problema do sofrimento e do silêncio de Deus. Não obstante as inúmeras tentativas de não culpá-Lo pelos nossos sofrimentos, temos de confessar que não há uma resposta satisfatória. Como transparece nesse texto de Is, o mal vem do pecado humano e somos responsáveis pela situação lastimável na qual estamos vivendo. Mas também nos mostra, nas entrelinhas da perícope analisada, que Deus se identifica com o povo, fazendo-se Ele mesmo um sofredor, está lá no exílio, no sofrimento, na perseguição, pois é Pai. Apesar das dúvidas explicitadas na lamentação de Is 63,15-64,15, podemos trazer a certeza de que Deus Pai-Mãe não nos deixa sós no sofrimento. Ele sofre conosco. Como afirma Ellacuría (1990, p. 332):

Dios "interviene sin cesar en la historia y revela su voluntad a través de los acontecimientos. [...] Se apunta así a la historia humana como campo privilegiado para mostrar la irrupción trascendente de Dios como novedad imprevisible que abre la contingencia humana a la esperanza divina".

Assim, se por um lado essa perícope alimenta nossa esperança de que Deus é Pai e será nosso resgatador; por outro, nos convida a também confessar nossos pecados, rever nossas infidelidades, nosso afastamento do Deus da Vida e nos interpela a assumir nossa responsabilidade. Convoca-nos a sermos construtores de uma sociedade justa e fraterna, de sermos sensíveis diante da dor e do sofrimento do oprimido, a não conter a comoção de nossas entranhas, a superar nossa indiferença e sermos compassivos. 


\section{Referências}

BLENKINSOPP, J. Isaiah 56-66: a new translation with introduction and commentary. New York: Doubleday, 2003. (The Anchor Bible, 19B).

BOVATI, P. Ristabilire la giustizia: procedure, vocabolario, orientamenti. Roma: Pontificio Istituto Biblico, 2005. (Analecta Biblica, 110).

CHILDS, B. S. Isaia. Brescia: Queriniana, 2005. (Commentari Biblici).

COLLINS, J. J. A imaginação apocalíptica: uma introdução à literatura apocalíptica judaica. São Paulo: Paulus, 2010. (Academia Bíblica).

ELLACURÍA, I. Historicidad de la salvación cristiana. In: ELLACURÍA, I.; SOBRINO, J. (Eds.). Mysterium Liberationis: conceptos fundamentales de teología de la liberación. Madrid: Trotta, 1990. v.1. p. 323-372.

MARCONCINI, B. "Tu, Signore, sei il nostro padre" (Is 63,16). Parola, Spirito e Vita, Bologna, v. 39, n. 1. p. 57-69, genn./ giugno 1999.

NISKANEN, P. Yhwh as father, redeemer, and potter in Isaiah 63:7-64:11. The Catholic Biblical Quarterly, Washington, v. 68, n. 3, p. 397-407, July 2006.

SCHÜNGEL-STRAUMANN, H. Deus como mãe em Oséias 11. In: BRENNER, A. (Org.). Profetas a partir de uma leitura de gênero. São Paulo: Paulinas, 2003. p. 265297. (A Bíblia: uma leitura de gênero).

SIMIAN YOFRE, H. Isaías. In: GUIJARRO OPORTO, S.; SALVADOR GARCÍA, M. (Ed.). Comentário ao Antigo Testamento. São Paulo: Ave-Maria, 2004. v. 2, p. 23-102.

PRIOTTO, M. Esodo: nuova versione, introduzione e commento. Milano: Paoline, 2014. (I Libri Biblicci. Primo Testamento, 2).

Artigo submetido em 28.09.18 e aprovado em 20.11.18.

Zuleica Aparecida Silvano pertence à Congregação das Filhas de São Paulo (Paulina), é doutora em Teologia Bíblica pela Faculdade Jesuíta de Filosofia e Teologia (FAJE), em Belo Horizonte (2018), é professora na Faculdade Jesuíta de Filosofia e Teologia -FAJE, assessora no Serviço de Animação Bíblica (SAB/ Paulinas). É membro da Associação Brasileira de Pesquisa Bíblica (ABIB). Orcid.org/0000-0002-0988-9200. E-mail: zuleica.silvano@paulinas.com.br

Endereço: Av. Afonso Pena, 2142, 6० andar

Funcionários

30.130-007 Belo Horizonte - MG 